$\approx$ ISSES

ก

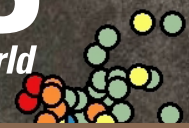

\title{
Satellite Tracking and Geospatial Analysis of Feral Swine and Their Habitat Use in Louisiana and Mississippi
}

Feral swine (Sus scrofa) is an invasive species that was first introduced to the continental United States in the 1500s by European explorers. Also known as feral hogs or feral pigs, the animals typically weigh about 200 pounds (up to 400 pounds) (Perot, 2011), have characteristic tusks up to 3 inches long, are territorial, and live in groups (fig. 1), except for the boars, who are solitary and typically interact with sows only to breed. They have an average litter size of 5-6 piglets and occasionally two litters per year (Barrett and Birmingham, 1994), and because they have few natural predators, survival of their young can be nearly 100 percent (West and others, 2009).

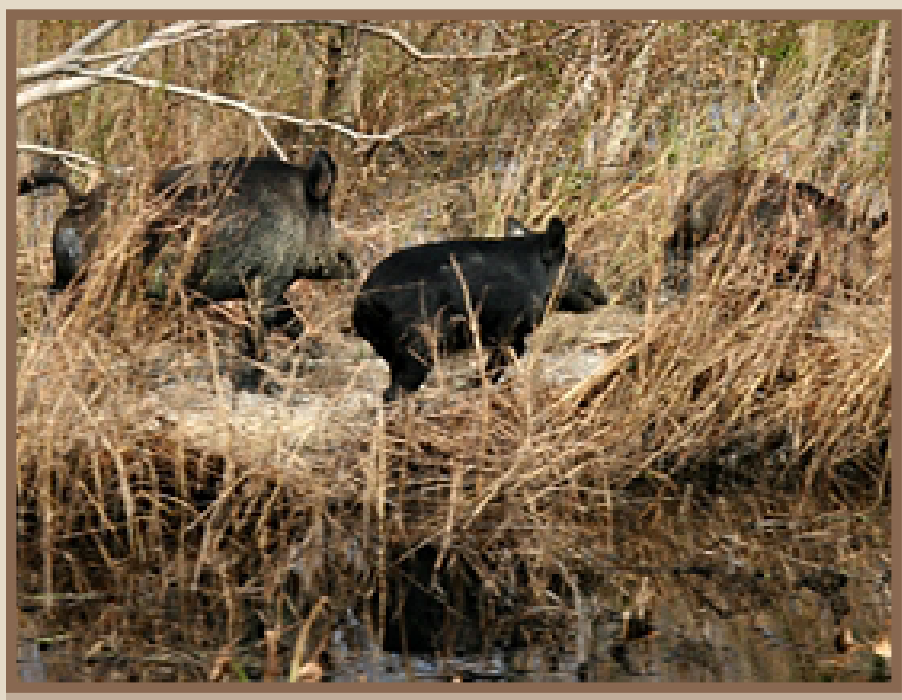

Figure 1. A group of feral swine in marsh lands. Photograph courtesy of Tom MacKenzie, U.S. Fish and Wildlife Service.

Feral swine root, or dig, for food and create wallows, thereby destroying sensitive vegetation, displacing native wildlife, and ultimately leading to loss of habitat quality and value. In coastal wetlands, their rooting decreases underground production and expansion of the root zone, exacerbating coastal erosion and land loss (Ashe, 2009). Rooting activities in forested habitats impact forest regeneration and vegetation structure and may lead to increases in invasive plants, including Chinese tallow tree (Triadica sebifera) and cogon grass

(Imperata cylindrical). Hurricane protection levees and other water control structures that protect human communities have been severely damaged by rooting. In agricultural lands, feral swine consume crops, damage crop fields, prey on livestock, and create potentially hazardous conditions for the operation of farm equipment (Hamrick and others, 2011). Feral swine compete for food directly with many native animals - such as ducks, deer, squirrels, turkeys, and bears - and destroy habitat for many other wildlife species, including ground-nesting birds (Ashe, 2009; West and others, 2009; Perot, 2011). Their omnivorous diet includes ground-nesting birds and eggs, reptiles (fig. 2), and amphibians. Further, feral swine are known to spread more than 30 diseases and 37 parasites, including swine brucellosis and pseudorabies, which can have devastating effects on livestock, wildlife, and humans (Ashe, 2009).

Because of the detrimental impacts of this invasive species, many public lands implement feral swine control programs on an annual basis. In Louisiana, several refuges allow trapping by permitted individuals and hunting by licensed individuals. This activity is not enough to control or prevent an increase in swine populations, however, because of their distribution beyond the boundaries of public lands.

Currently, little is known about feral swine populations, their habitat use and movement patterns, and the resulting habitat destruction in Louisiana and Mississippi. To abate this lack of knowledge, researchers at the U.S. Geological Survey (USGS) National Wetlands Research Center (NWRC) - in cooperation with the U.S. Fish and Wildlife Service, the Louisiana Department of Wildlife and Fisheries, and several large landholding companies - are using collars equipped with

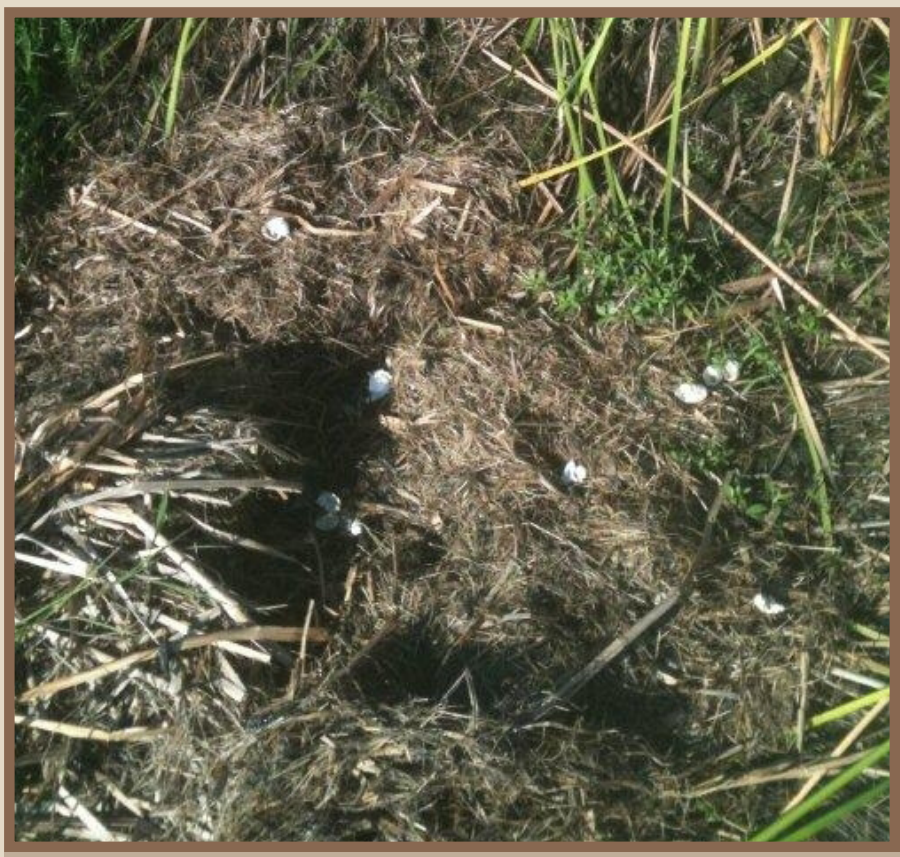

Figure 2. In Louisiana alone, 590 alligator nests were damaged or destroyed by feral swine on 36 separate properties across the State (Elsey and others, 2012). Photograph courtesy of Jeff Donald. 
Global Positioning System (GPS) receivers (fig. 3) to track feral swine in Louisiana and Mississippi to examine population movement patterns, document destruction of habitat and wildlife, and help increase and facilitate removal - the preferred control measure for feral swine populations. The NWRC researchers are using the "Judas pig" system of attaching GPS-satellite telemetry collars to select feral swine to (1) track movement patterns on the landscape, (2) document habitat destruction and effects on native wildlife, and (3) improve removal rates. Once a collar has been attached to an individual, usually a large boar or sow (fig. 4), it is released and returns to its group. The group's movements and locations can then be tracked through the movement of the collared individual, the "Judas pig," allowing researchers and managers to better target removal efforts.

The use of GPS telemetry will allow the NWRC researchers to monitor feral swine movements daily (fig. 5). The results of this research will provide natural resource managers with more information for managing and responding to the impacts of this invasive species.

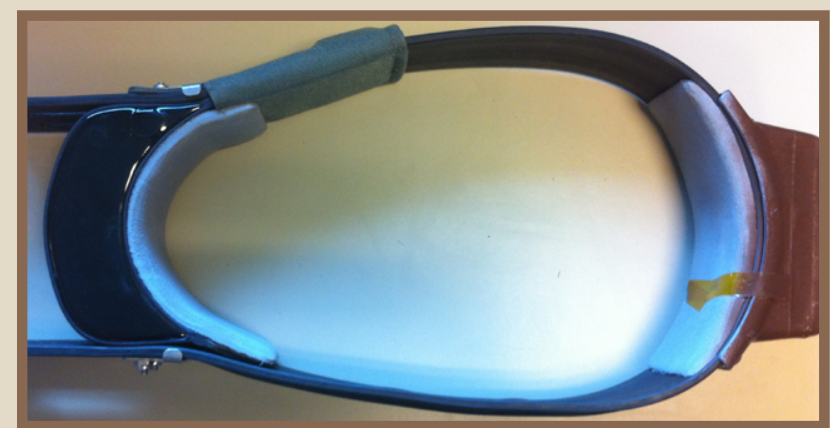

Figure 3. An example of the tracking collars with Global Positioning System (GPS) receivers that are used to track feral swine.

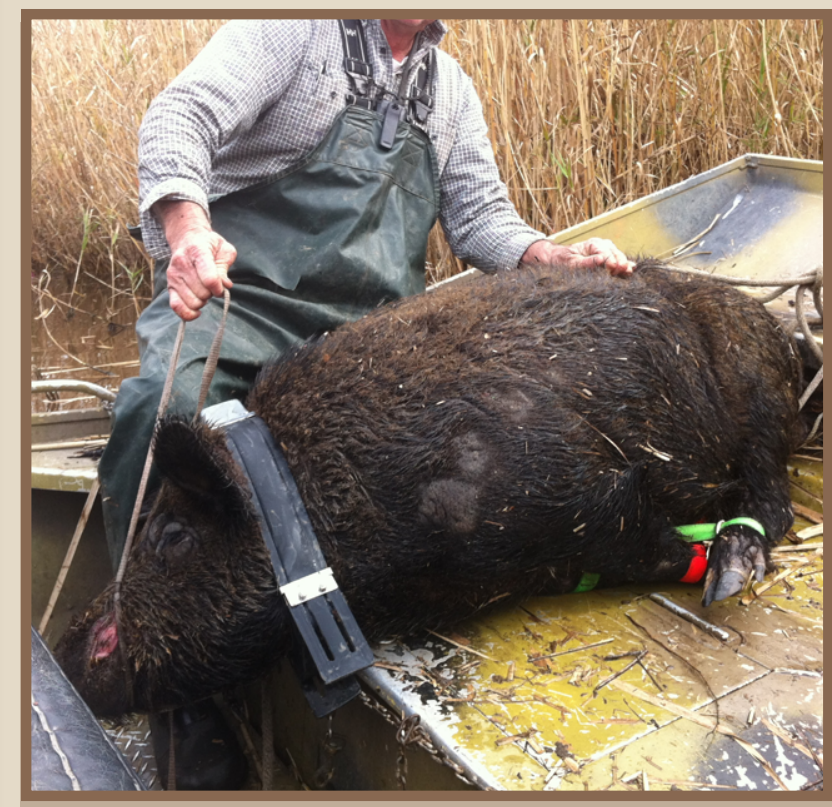

Figure 4. A boar of about 280 pounds near Pecan Island, Louisiana, with a tracking collar attached.

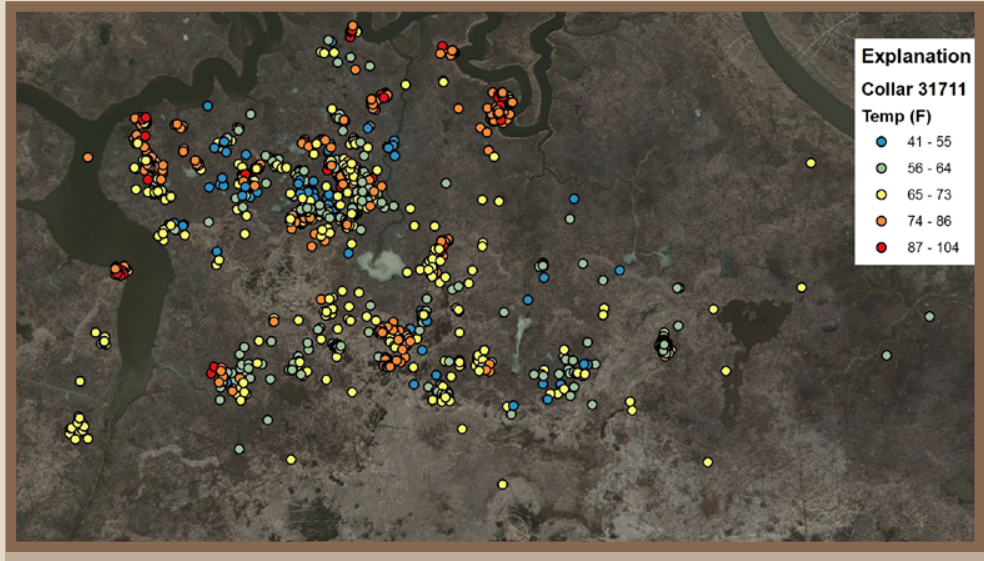

Figure 5. Tracked movements of a collared "Judas pig" near Pearlington, Mississippi. Color-coded ambient temperature data show that during the hottest times of day the feral swine is bedded down. These identified locations can be used to focus removal efforts.

\section{References}

Ashe, Daniel, 2009, S. 1965, Feral swine eradication and control pilot program act of 2009: accessed April 17, 2012, at http://www.doi. gov/ocl/2006/VariousBills_120309.htm.

Barrett, R.H., and Birmingham, G.H., 1994, Wild pigs, in Hygnstrom, S.E., Timm, R.M., and Larsen, G.E., eds., Prevention and control of wildlife damage: Lincoln, University of Nebraska Cooperative Extension Service, p. D65-D70.

Elsey, R.C., Mouton, E.C., and Kinler, Noel, in press, Effects of feral swine (Sus scrofa) on alligator (Alligator mississippiensis) nests in Louisiana: The Southern Naturalist.

Hamrick, Bill, Smith, Mark, Jaworowski, Chris, and Strickland, Bronson, 2011, A landowner's guide for wild pig managementPractical methods for wild pig control: Mississippi State University Extension Service and Alabama Cooperative Extension System.

Perot, Michael, 2011, Coping with feral hogs: Louisiana Department of Wildlife and Fisheries Wildlife Division, Private Lands Program.

West, B.C., Cooper, A.L., and Armstrong, J.B., 2009, Managing wild pigs - A technical guide: Human-Wildlife Interactions Monograph 1, 55 p.

\section{-Stephen B. Hartley, ${ }^{1}$ Kathryn A. Spear, ${ }^{1}$ and Buddy L. Goatcher ${ }^{2}$ ${ }^{1}$ U.S. Geological Survey. \\ ${ }^{2}$ U.S. Army Corps of Engineers.}

\author{
For more information, please contact: \\ Director, National Wetlands Research Center \\ U.S. Geological Survey \\ 700 Cajundome Blvd. \\ Lafayette, LA 70506 \\ http://www.nwrc.usgs.gov
}

Publishing support provided by

Lafayette Publishing Service Center 